\title{
Utilization Juice Wastes as Corn Replacement in the Broiler Diet
}

\author{
Yose Rizal, Maria Endo Mahata, Mira Andriani, and Guoyao Wu
}

\begin{abstract}
An experiment was conducted with 80 unsexed broilers of the Arbor Acress strain to determine the capability of a carrot and fruit juice wastes mixture (carrot, apple, manggo, avocado, orange, melon and Dutch egg plant) in the same proportion for replacing corn in broiler diet. This study involved a completely randomized design (CRD) with 5 treatments $(0,5,10,15$, and $20 \%$ of juice wastes mixture in diets) and 4 replicates per treatment. Diets were isonitrogenous (22\% crude protein) and isocaloric (3000 kcal $/ \mathrm{kg}$ diet). Measured variables were feed consumption, average daily gain, feed conversion, as well as percentages of abdominal fat pad, carcass, digestive organs (liver, pancreas and gizzard), and heart. Data were analyzed by analysis of variance for CRD. Increasing juice wastes mixture levels in diets increased feed consumption $(\mathrm{P}<0.05)$ and average daily gain $(\mathrm{P}<0.01)$, while improving feed utilization efficiency $(\mathrm{P}<0.05)$. These treatments also affected $(\mathrm{P}<0.05)$ abdominal fat pad percentage but had no effect $(\mathrm{P}>0.05)$ on carcass, liver, pancreas, gizzard or heart percentages. In conclusion, up to $20 \%$ of juice wastes mixture could be included for the broiler diet to effectively replace up to $40 \%$ corn in the diet.
\end{abstract}

Keywords - average daily gain, feed consumption, feed conversion, juice waste mixture

\section{INTRODUCTION}

Conventional feed stuffs which often available for poultry diets consist of corn, rice bran, soybean meal, coconut meal, fish meal, and vitamin as well as mineral supplements. Some of corn, soybean meal and fish meal in Indonesia are still imported from abroad. It is resulted in a high cost of diets for poultry. Many attempts have been conducted to reduce the cost of these diets. Feed diversification in the poultry diet is one of many attempts to reduce the cost of feed in the poultry industry.

The utilization of waste materials from agricultural or industrial wastes (by-products) is often applied to overcome the problem of feed shortage in poultry industry. Olive pulp can be included up to $7.5 \%$ in the ration of broilers [1]. Reference [2] found that the apple by-product could be used in broiler diets.

Yose Rizal is with the Faculty of Animal Science, University of Andalas,Padang, West Sumatra, Indonesia (corresponding author, phone: +6275172916; fax: +6275171464; e-mail: yrizal@faterna.unand.ac.id) Maria Endo Mahata is with the Faculty of Animal Science, University of Andalas, Padang, West Sumatra, Indonesia (e-mail: mariamahata2002@yahoo.com)

Mira Andriani is a graduate student at the Faculty of Animal Science,University of Andalas, Padang, West Sumatra, Indonesia

Guoyao Wu is with the Department of Animal Science, Texas A\&M University, College Station, TX 77843 USA (e-mail:g-wu@neo.tamu.edu)
Tomato pomace of different processing methods could be included up to $10 \%$ in broiler diets without affecting live body weight [3]. Reference [4] reported that the dried sweet orange rind could also be used to replace dietary maize in broiler diets at the $15 \%$ level.

Fruits juice wastes might also be included in poultry diets because they still have the nutrients which are available for poultry. However, there are no data available on the amount of these fruits juice wastes in Indonesia. Based on the survey in Padang city, West Sumatra, it was found that there were at least 40 fruit juice counters which produce approximately 30 $\mathrm{kg}$ juice waste/counter/day (total $1200 \mathrm{~kg} /$ day). It has not included the juice wastes from restaurants "unpublished" [5]. In addition, the more available juice wastes in this city were from the processing of carrot (Daucus carotta), apple (Mallus sylvestris), manggo (Mangifera indica), avocado (Persea americana), orange (Citrus sp.), water melon (Cucumis melo $L$ ), and Dutch egg plant (Cyphomandra betacea Sendtn.).

The results of chemical analysis at the Feed Technology and Industry Laboratory, Faculty of Animal Science, University of Andalas in 2009 indicated that the nutrient content of carrot and fruit juice wastes mixture in the same proportion were as follows: crude protein $8.4 \%$, crude fiber $17.1 \%$, ether extract $6.2 \%$, Ca $0.09 \%$ and P $0.01 \%$, and betacarotene $24 \mathrm{ppm}$ (conducted at West Sumatra Biota Laboratory, University of Andalas in 2009). The results of amino acids analysis of this juice waste mixture at the Nutrition Laboratory, Department of Animal Science, Texas A \& M University in 2009 as compared to corn [6] are depicted in Table I. The crude protein content of this juice waste mixture is similar to corn [6]. The tryptophan content of this juice waste mixture is 4.0 times, lysine 1.6 times, glycine 1.6 times and threonine 1.3 times of the corn.

There is no information available on the utilization of carrot and fruits juice wastes mixture in the poultry diets. An experiment was conducted to determine the effects of carrot and fruits juice wastes mixture in diets on the performance of broilers. 
TABLE I

Amino ACID CONTENT OF JUICE WASTE MiXture As COMPARED TO CORN.

\begin{tabular}{|c|c|c|c|}
\hline \multirow[t]{2}{*}{ No. } & \multirow[t]{2}{*}{ Amino Acids } & \multicolumn{2}{|c|}{ Amino Acid Content (\%) } \\
\hline & & Corn $^{1}$ & $\begin{array}{c}\text { Juice Waste } \\
\text { Mixture }^{2}\end{array}$ \\
\hline 1. & Aspartate & - & 0.71 \\
\hline 2. & Glutamate & - & 0.98 \\
\hline 3. & Serine & 0.37 & 0.46 \\
\hline 4. & Histidine & 0.23 & 0.14 \\
\hline 5. & Glycine & 0.33 & 0.54 \\
\hline 6. & Threonine & 0.29 & 0.39 \\
\hline 7. & Arginine & 0.38 & 0.37 \\
\hline 8. & Alanine & - & 0.54 \\
\hline 9. & Tyrosine & 0.30 & 0.43 \\
\hline 10. & Methionine & 0.18 & 0.13 \\
\hline 11. & Valine & 0.40 & 0.44 \\
\hline 12. & Phenylalanine & 0.38 & 0.37 \\
\hline 13. & Iso Leucine & 0.29 & 0.34 \\
\hline 14. & Leucine & 1.00 & 0.54 \\
\hline 15. & Lysine & 0.26 & 0.42 \\
\hline 16. & Proline & - & 0.68 \\
\hline 17. & Cysteine & 0.18 & 0.05 \\
\hline 18. & Tryptophan & 0.06 & 0.23 \\
\hline
\end{tabular}

${ }^{1}$ NRC. 1994. Nutrient Requirements of Poultry.

2 Analyzed at Animal Nutrition Laboratory, Texas A\&M University, USA in 2009.

\section{METHOD OF EXPERIMENT}

An experiment was conducted to determine the effects of utilization of juice wastes mixture in the same proportion of carrot (Daucus carotta), apple (Mallus sylvestris), manggo (Mangifera indica), avocado (Persea americana), orange (Citrus sp.), water melon (Cucumis melo L), and Dutch egg plant (Cyphomandra betacea Sendtn.) for replacing corn in the diet on the broiler performance. Eighty day old chicks of the strain of Arbor Acress were assigned to experimental diets of 5 levels of juice wastes mixtures (0, 5, 10, 15 and 20\%) in a completely randomized design with 4 replications. Diets were formulated in iso-nitrogenous (22\% crude protein) and isocaloric (3000 kcal $/ \mathrm{kg}$ diet) as described in Table II. Diets and water were provided ad libitum. Broilers were kept under continues light.

Measured variables were: feed consumption, average daily gain, feed conversion, abdominal fat pad percentage, carcass percentage, liver percentage, pancreas percentage, gizzard percentage and heart percentage. One broiler per unit of experiment was slaughter to obtain abdominal fat pad, carcass, liver, pancreas, gizzard and heart percentages.

All of the data were analyzed by analysis of variance of Randomized Completely Design according to [7]. The experiment was performed at the Laboratory of Non-Ruminant
Nutrition, Faculty of Animal Science, University of Andalas in 2009.

TABLE II

COMPOSITION, NUTRIENT AND METABOLIZABLE ENERGY CONTENTS OF EXPERIMENTAL DIETS.

\begin{tabular}{|c|c|c|c|c|c|}
\hline \multirow[b]{2}{*}{ Ingredients } & \multicolumn{5}{|c|}{ Experimental Diets } \\
\hline & A & B & C & D & E \\
\hline Corn & 50.00 & 45.00 & 40.00 & 35.00 & 30.00 \\
\hline $\begin{array}{c}\text { Juice waste } \\
\text { mixture }\end{array}$ & 0.00 & 5.00 & 10.00 & 15.00 & 20.00 \\
\hline Rice bran & 12.00 & 12.00 & 12.00 & 12.00 & 12.00 \\
\hline Fish meal & 21.00 & 21.00 & 21.00 & 21.00 & 21.00 \\
\hline Soybean meal & 15.00 & 15.00 & 15.00 & 15.00 & 15.00 \\
\hline Coconut oil & 2.00 & 2.00 & 2.00 & 2.00 & 2.00 \\
\hline TOTAL & 100.00 & 100.00 & 100.00 & 100.00 & 100.00 \\
\hline \multicolumn{6}{|l|}{ Calculated: } \\
\hline Crude Protein & 22.26 & 22.25 & 22.24 & 22.23 & 22.22 \\
\hline Ether Extract & 6.52 & 6.63 & 6.75 & 6.87 & 6.98 \\
\hline Crude Fiber & 3.40 & 4.66 & 5.41 & 6.17 & 6.92 \\
\hline $\mathrm{Ca}$ & 1.16 & 1.16 & 1.17 & 1.17 & 1.17 \\
\hline P total & 0.56 & 0.56 & 0.56 & 0.56 & 0.56 \\
\hline $\mathrm{ME}$ & 3035.40 & 3026.90 & 3018.40 & 3009.90 & 3001.40 \\
\hline Lysine & 1.35 & 1.36 & 1.36 & 1.37 & 1.38 \\
\hline Methionine & 0.48 & 0.48 & 0.47 & 0.47 & 0.47 \\
\hline Threonine & 0.87 & 0.88 & 0.88 & 0.89 & 0.89 \\
\hline Tryptophan & 0.23 & 0.24 & 0.25 & 0.26 & 0.26 \\
\hline
\end{tabular}

\section{RESUlTS AND DisCUSSION}

\section{A. Feed Consumption, Average Daily Gain and Feed Conversion}

The mean of feed consumption, average daily gain and feed conversion is depicted in Table III. The feed consumption of broilers was affected $(\mathrm{P}<0.05)$ by treatments. The increase in the level of juice wastes mixture augmented the feed consumption of broilers. This was probably due to the increase in the palatability of diets caused by the acid content in the diet. According to [8] the addition of propionate in the diet increased feed consumption of broiler chicks.

Average daily gain of broilers was highly affected $(\mathrm{P}<0.01)$ by treatments. Increasing in the juice wastes mixture in diets increased the average daily gain of broilers. Some causes of the increase in average daily gain were the high in amino acids contents in the juice wastes mixture such as tryptophan, lysine and threonine. According to [9] and [10], broilers are more responsive to high lysine in the diet. Lysine increases the growth rate of broilers [11]. Tryptophan and threonine are also necessasy for growing chicks [12]-[14]. Besides, glycine was also important lately for growing chicks in low quality protein diet [15]-[16]. 
Feed conversion was significantly influenced $(\mathrm{P}<0.05)$ by the treatments. The increase in the level of juice wastes mixture in diets improved the feed conversion or the eficiency of feed utilization of broilers. It indicated that the increase in the average daily gain was not in the same proportion with the increase in the feed consumption. More daily gain was obtained from every unit of feed consumption. It could be related to the high of some amino acids (tryptophan, lysine, threonine and glycine) in juice wastes mixture as compared to corn. However, the content of those amino acids (Table II) in experimental diets already meets the requirement for broilers according to [6]. It might be also the influence of other substances such as vitamins in juice wastes mixture which improved the efficiency of feed utilization of broiler. These substances need further investigation. The high in average daily gain resulted in improving the efficiency of feed utilization. The utilization up to $20 \%$ of juice wastes mixture in the diet improve the efficiency of feed utilization by broilers.

TABLE III

MeAn of FeEd Consumption, Average Daily Gain And FEed CONSUMPTION OF BROILERS IN EACH TREATMENT

\begin{tabular}{cccc}
\hline Treatment & $\begin{array}{c}\text { Feed Consumption } \\
\text { (g/head/day) }\end{array}$ & $\begin{array}{c}\text { ADG } \\
\text { (g/head/day) }\end{array}$ & \\
\hline $\mathrm{A}$ & $63.08^{\mathrm{a}}$ & $32.37^{\mathrm{a}}$ & $1.95^{\mathrm{a}}$ \\
$\mathrm{B}$ & $63.53^{\mathrm{a}}$ & $33.21^{\mathrm{a}}$ & $1.92^{\mathrm{ab}}$ \\
$\mathrm{C}$ & $69.19^{\mathrm{b}}$ & $39.06^{\mathrm{b}}$ & $1.78^{\mathrm{bc}}$ \\
$\mathrm{D}$ & $69.89^{\mathrm{b}}$ & $40.26^{\mathrm{b}}$ & $1.74^{\mathrm{c}}$ \\
$\mathrm{E}$ & $69.29^{\mathrm{b}}$ & $39.93^{\mathrm{b}}$ & $1.74^{\mathrm{c}}$ \\
\hline $\mathrm{SE}^{1}$ & & & \\
\hline
\end{tabular}

${ }^{1}$ Standard Error of the Mean

a,b The mean with different superscripts at the same column differs statistically $(\mathrm{P}<0,05)$

\section{B. Abdominal Fat Pad, Carcass, Liver, Pancreas, Gizzard and Heart Percentages}

Abdominal fat pad and carcass percentages are shown in Table IV. Abdominal fat pad percentage was influenced $(\mathrm{P}<0.05)$ by treatments. The enhancement of the level of juice wastes mixture in the diet reduced the abdominal fat pad percentage of broilers. The decrease in this abdominal fat pad percentage was due the increase in the fiber content in the diets. Reference [17] stated that the crude fiber in the diet could reduce the fat content of broilers. This crude fiber content also limits the inclusion of juice wastes mixture in the diet. Carcass percentage of broilers was not affected by treatments.

Liver, pancreas, gizzard and heart percentages were performed in Table V). These liver, pancreas, gizzard and heart percentages were also not affected by the increase in the level of juice waste mixture in diets.
TABLE IV

MeAn of ABdominal FAt PAD AND CARCASS PERCENTAgES of BroIlers IN EVERY TREATMENTS.

\begin{tabular}{ccc}
\hline Treatments & Abdominal Fat Pad (\%) & Carcass (\%) \\
\hline A & $1.41^{\mathrm{b}}$ & 68.61 \\
$\mathrm{~B}$ & $1.76^{\mathrm{a}}$ & 70.73 \\
$\mathrm{C}$ & $1.52^{\mathrm{ab}}$ & 69.03 \\
$\mathrm{D}$ & $1.32^{\mathrm{b}}$ & 68.56 \\
$\mathrm{E}$ & $1.28^{\mathrm{b}}$ & 67.53 \\
\hline SE & 0.11 & 1.20 \\
\hline
\end{tabular}

${ }^{1}$ Standard Error of the Mean.

${ }^{\mathrm{a}, \mathrm{b}}$ The mean with different superscripts at the same column differs statistically $(\mathrm{P}<0,05)$

TABLE V

The Mean of Liver, Pancreas, Gizzard and Heart Percentages of BROILERS IN EVERY TREATMENT ${ }^{\text {NS }}$

\begin{tabular}{ccccc}
\hline Treatments & Liver (\%) & Pancreas (\%) & Gizzard (\%) & Heart (\%) \\
\hline A & 1.70 & 0.23 & 2.49 & 0.60 \\
B & 1.87 & 0.26 & 2.56 & 0.58 \\
C & 1.73 & 0.33 & 2.45 & 0.55 \\
D & 1.77 & 0.24 & 2.56 & 0.50 \\
E & 2.02 & 0.24 & 2.27 & 0.55 \\
\hline SE & 0.11 & 0.05 & 0.15 & 0.04 \\
\hline
\end{tabular}

${ }^{\text {ns }}$ Non-significantly different $(\mathrm{P}>0,05)$

\section{CONCLUSION}

The carrot and fruits juice wastes mixture could be included up to $20 \%$ for broiler diets to effectively replace $40 \%$ corn in the diet. High crude fiber content in juice wastes mixture limits its utilization in the broiler diet. Further investigation is necessary to increase the inclusion of this juice wastes mixture in the broiler diet.

\section{ACKNOWLEDGEMENT}

This experiment was supported by the Fundamental Research Funding Program provided by Directorate General of Higher Education, Ministry of National Education of the Republic of Indonesia. I am very grateful to the Dean of the Faculty of Animal Science and the Rector of the University of Andalas who have given me a chance to compete with others in obtaining this funding. My special gratitude is also directed to the Director General of Higher Education and the Minister of National Education who have provided this funding.

\section{REFERENCES}

[1] E. Rabayaa, J. M. Abo Omar and R. A. Othman, Utilization of olive pulp in broiler rations. An-Najah University J. Res., Vol. 15. 2001.

[2] Zafar, F., M. Idrees and Z. Ahmed, Use of apple by-products in poultry rations of broiler chicks in Karachi. Pak. J. Physiol. 1:1-2. 2005.

[3] N. A. Al-Betawi, Preliminary study on tomato pomace as unusual feed stuff in broiler diets. Pak. J. of Nutrition 4 (1): 57-63. 2005. 
[4] O. I. A. Oluremi, V. O. Ojighen and E. H. Ejembi, The nutritive potentials of sweet orange (Citrus sinensis) rind in broiler production. Int. J. of Poult. Sci., 5 (7): 613-617. 2006.

[5] M. E. Mahata, Survey on fruits juice wastes in Padang city, "unpublished.

[6] NRC. Nutrient Requirements of Poultry. Nine Revised Edition. National Academy Press. Washington DC. 1994.

[7] R. G. D. Steel and J. H. Torrie. Principles and Procedures Statistics a Biometric Approach. P.T. Gramedia Pustaka Utama, Jakarta. 1991.

[8] N. A. G. Cave, Effect of dietary propionic acids on feed intake in chicks. Poultry Sci. 63:131-134. 1984.

[9] S. F. Bilgili, E. T. Moran and N. Acar, Strain-cross response of heavy male broilers to dietary lysine in the finisher period. Poultry Sci. 71:850-858. 1992.

[10] H. M. Edwards, S. R. Fernandez and D. H. Baker, Maintenance lysine requirement and efficiency of using lysine for accretion of whole body lysine and protein in young chicks. Poultry Sci. 78:1407-1411. 1999.

[11] Y. Han and D. H. Baker, Lysine requirement of male and female broiler chicks during the period three to six weeks post hatching. Poultry Sci. 73:1739-1745. 1994
[12] A. P. Rosa, G. M. Pesti, H. M. Edwards Jr. and R. I. Bakalli, Threonine requirements of different broiler genotypes. Poult. Sci. 80:1710-1717. 2001a.

[13] A. P. Rosa, G. M. Pesti, H. M. Edwards Jr. and R. I. Bakalli, Tryptophan requirements of different broiler genotypes. Poult. Sci. 80:1718-1722. 2001b.

[14] A. S. Shan, , K. G. Steroling, G. M. Pesti, R. I. Bakalli, J. P. Driver and A. A. Tejedor, The influence of temperature on the threonine and tryptophan requirements of young broiler chicks. Poult. Sci. 82:11541162. 2003.

[15] D. H. Baker, Advances in protein-amino acid nutrition of poultry. Amino Acids. 37:29-41. 2009.

[16] D. W. Dean, T. D. Bidner and L. L. Southern, Glycine supplementation to low protein, amino acid-supplemented diets supports optimal performance of broiler chicks. Poult. Sci. 85:288-296. 2006.

[17] J. A. Cherry and D. E. Jones, Dietary cellulose, wheat bran, and fishmeal in relation to hepatic lipids, serum lipids, and lipid excretion in laying hens. Poultry Sci. 61:1973-1980. 1982. 